\title{
Changes in peripheral blood Th1 and Th2 cells in rat liver transplantation under different immune statuses
}

\author{
Z.-L. Yang, K. Cheng, H.G. Sun, W.W. Zou and M.M. Wu \\ Department of Thyroid and Breast Surgery, \\ Affiliated Hospital of Binzhou Medical College, Shandong Binzhou, China \\ Corresponding author: Z.-L. Yang \\ E-mail: yangzhenlin_yzl@yeah.net
}

Genet. Mol. Res. 12 (4): 6939-6946 (2013)

Received November 13, 2012

Accepted April 29, 2013

Published December 19, 2013

DOI http://dx.doi.org/10.4238/2013.December.19.13

\begin{abstract}
In this study, early expressions of peripheral blood Th1 and Th2 cells were documented following rat liver transplantation and related to immune status. Rats were divided into 3 groups: group A (control): syngeneic transplantation (Brown Norway $(\mathrm{BN}) \rightarrow \mathrm{BN}$ ); group B: allogeneic transplantation + cyclosporine A (CsA); group C: allogeneic transplantation (Lewis $\rightarrow \mathrm{BN}$ ). Flow cytometry was used to analyze peripheral blood $\mathrm{CD}^{+} \mathrm{CD} 45 \mathrm{RC}$ percentage on days $1,3,5,7$, and 14 following transplantation, and were compared to graft rejection pathological grades and receptor survival times. The average survival of groups A and B exceeded 100 days, which was significantly longer than that of group $\mathrm{C}(3.56 \pm 34.3$ days $)$. With the exception of the first day, rejection grades were significantly higher in groups $\mathrm{C}$ and $\mathrm{B}$ compared to group $\mathrm{A}$, and group $\mathrm{C}$ rejection grades were significantly higher than those of group $\mathrm{B}$. Three days after transplantation, the $\mathrm{CD}^{+} \mathrm{CD} 45 \mathrm{RC}^{+}$to $\mathrm{CD}^{+} \mathrm{CD} 45 \mathrm{RC}^{-}$ratio of group $\mathrm{C}$ was significantly higher than that of groups $\mathrm{A}$ and $\mathrm{B}$. In group $\mathrm{B}$, the $\mathrm{CD}^{+} \mathrm{CD} 45 \mathrm{RC}^{+}$ to $\mathrm{CD}^{+} \mathrm{CD} 45 \mathrm{RC}^{-}$ratio was negatively correlated to the rejection grade $(r=-0.565, P<0.01)$, whereas this relationship was positive in
\end{abstract}


group $\mathrm{C}(\mathrm{r}=0.745, \mathrm{P}<0.01)$. In conclusion, peripheral blood Th1 was highly expressed during rejection in rat liver grafts. Peripheral blood Th2 tended to increase early under rejection inhibition with CsA, and its high expression level may correlate with long-term acceptance or tolerance of transplanted livers.

Key words: Liver transplantation; Th1/Th2; Cyclosporine A

\section{INTRODUCTION}

Liver transplantation had its inception in 1963, when the diseased liver of a 3-yearold child with extrahepatic biliary atresia was replaced (Starzl et al., 1987). Since then, subsequent successes have established liver transplantation as standard therapy for advanced chronic liver disease. Since 1983, the 1-year survival rate has increased from 25 to $78 \%$, depending on the age and health of the recipient, the underlying condition, and various other clinical considerations. Liver transplantation is recommended for chronic end-stage liver disease, fulminant acute liver failure, and cancer limited to the liver (Mowat, 1987). The longterm survival rates for clinical organ transplantation have improved substantially, and it has now become the best treatment option for patients with end-stage organ failure. Nevertheless, allograft rejection remains a major obstacle to organ transplantation. Rat liver transplantation is currently the most common experimental liver transplantation animal model and has provided valuable data for clinical practices. In this study, we use inbred Lewis and Brown Norway $(\mathrm{BN})$ rats to examine the early expression of peripheral blood Th1/Th2 cells following liver transplantation.

\section{MATERIAL AND METHODS}

\section{Experimental animals}

Inbred, specific pathogen-free (SPF) and viral antibody-free (VAF) male Lewis rats, weighing 200-250 g, were purchased from Beijing Vital River Laboratory Animal Technology Co., Ltd. These rats were used as donors in the experiments.

Inbred SPF/VAF male BN rats, weighing 200-250 g, purchased from Beijing Vital River Laboratory Animal Technology Co., Ltd., were the recipients in the experiments. We adopted an improved version of the Kamada cuff method to establish a model of liver transplantation (Kamada and Calne, 1983; Yang et al., 2006). All animals were maintained under standard conditions.

\section{Experimental animal groups}

Animals were divided into 3 experimental allograft groups: group A (control): $\mathrm{N}=36$, syngeneic transplantation $(\mathrm{BN} \rightarrow \mathrm{BN}$ ); group $\mathrm{B}: \mathrm{N}=36$, allogeneic transplantation (Lewis $\rightarrow$ $\mathrm{BN})+2.0 \mathrm{mg} \cdot \mathrm{kg}^{-1} \cdot \mathrm{day}^{-1}$ cyclosporine $\mathrm{A}(\mathrm{CsA})$ subcutaneous injection for 0-7 days; group C: $\mathrm{N}=36$, allogeneic transplantation group (Lewis $\rightarrow \mathrm{BN}$ ). In addition, subgroups were established (6 rats per group) to document survival periods. On days 1, 3, 5, 7, and 14 after trans- 
plantation, the transplanted liver was cut for pathology detection, and another set of subgroups were established to observe general post-transplantation effects and recipient survival times.

\section{Specimen collection}

Six rats were euthanized and specimens collected on the 1st, 3rd, 5th, 7th, and 14th days after transplantation.

\section{Pathological analysis}

Liver tissues were fixed in $10 \%$ neutral buffered formalin, made into a wax block, and sliced for rejection pathological examination.

\section{Flow cytometry analysis}

The Coulter EPICS XL cytometer (Coulter, Miami, FL, USA) was used for flow cytometry.

\section{Whole blood cell phenotype analysis}

Phenotypic blood analysis was performed by the two-color immunofluorescence method (Garvy et al., 1993) using the PE-mouse anti-rat CD45RC (clone: OX-22), FITCmouse anti-rat CD4 (clone: w3/25), and anti-mouse-IgG1 (A85-1) antibodies (Coulter).

Each subgroup was fed under standard conditions to observe their general condition and record survival times. Acute rejection grading was measured by reference to the Kemnitze criteria (Kemnitz et al., 1989): 0 grade, no rejection evident; 0-1st grade, exclusion tendencies, but not enough to diagnose: mild mixed cell infiltration of portal area, bile duct injury, no intravenous dermatitis; 1st grade, mild acute rejection: portal area with mild mononuclear cell infiltration, mainly lymphocytes, and partially visible mixed cells. Intravenous dermatitis is visible at the portal and/or central vein areas, liver parenchymal cell necrosis can be seen, more than $10 \%$ of the liver parenchyma area has visible mononuclear cell infiltration, and bile duct injury; 2nd grade, moderate acute rejection: mononuclear cell infiltration of the portal area can be seen more clearly, and degenerative changes of the liver parenchymal cells are evident. Non-bridging necrosis is visible in some areas, and mixed cell infiltration can be seen in the hepatic parenchymal area, mainly mononuclear cells, about $10-30 \%$ of the entire liver parenchyma, portal area and central venous dermatitis, and bile duct injury; 3rd grade, severe acute rejection: mixed cell infiltration can be obviously seen in the portal area and liver parenchyma, mainly mononuclear cells, more than $30 \%$ of the entire liver parenchyma has clear degeneration and necrosis, some bridging necrosis, portal area and central district intravenous dermatitis, and bile duct injury.

\section{Statistical analysis}

Means \pm SD of experimental data were subject to statistical analyses with the SPSS 11.0 software. Survival rates were assessed by the Kaplan-Meier method in each liver trans- 
plant recipient group. Other variables were analyzed by one-way analysis of variance and the $Q$ test. The Pearson test was used for correlation analysis among different parameters. Differences of $\mathrm{P}<0.05$ were considered to be statistically significant.

\section{RESULTS}

\section{General condition and survival time in each postoperative group}

All recipients were awakened within 0.5-1 h following surgery, given water 1-3 $\mathrm{h}$ later, and food 1 day later. Seven days following transplantation, group A rats had normal fur, weight gain, and all were long-living (more than 100 days). In contrast, group $\mathrm{C}$ rats had gray fur, ate poorly, had progressive weight loss, and were all dead by 28-38 days following the operation, with a median survival time of 33.3 days. In group B, 4 of 6 rats achieved longterm survival. Although their general condition was poor, they ate less, and their weight did not increase, their condition improved after withdrawal, mental status improved daily, activity increased, and their survival time was significantly longer, with a mean survival time greater than 100 days. Survival times of groups A and B were both significantly higher compared with that of group $\mathrm{C}(\mathrm{P}<0.001)$, whereas there was no difference in survival between groups $\mathrm{B}$ and A (Figure 1).

\section{Survival of recipient in different groups}

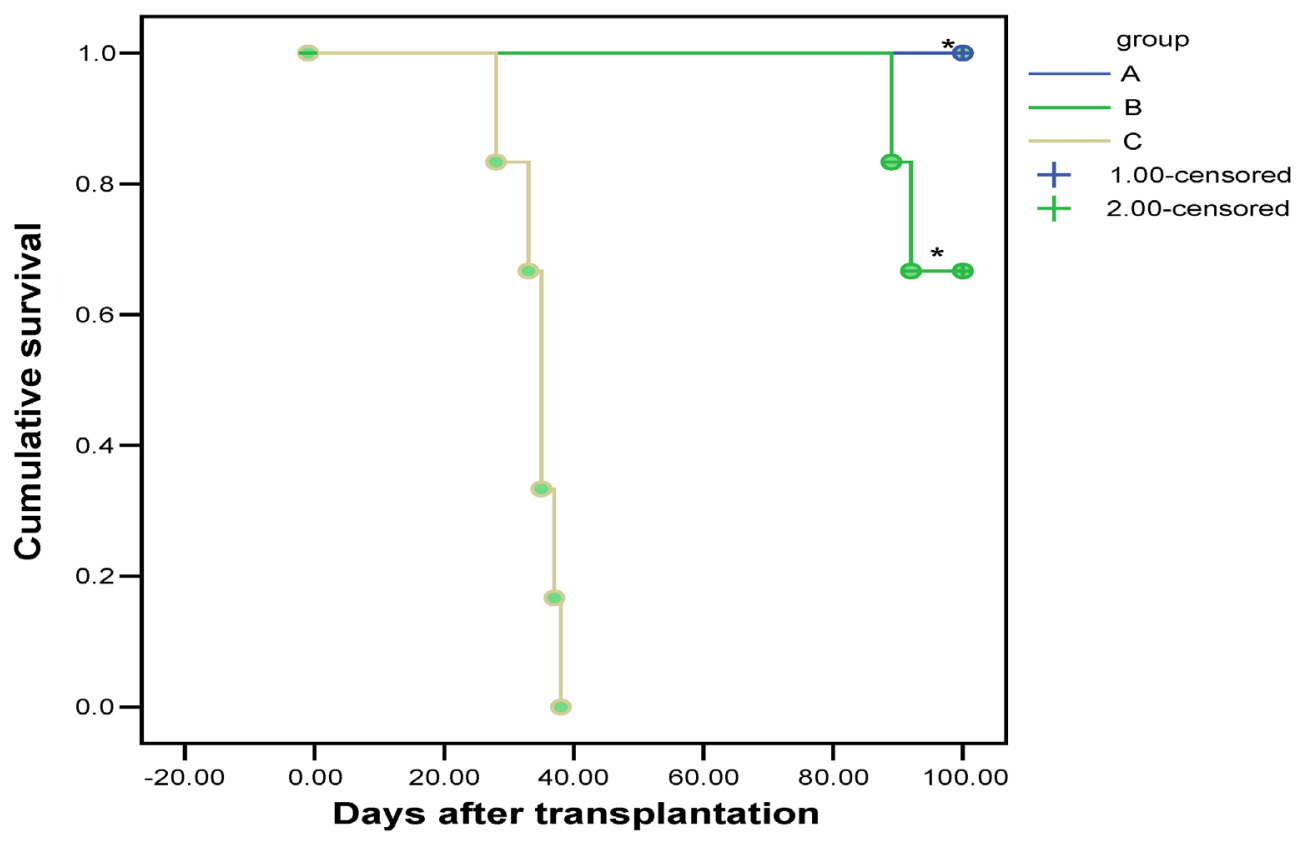

Figure 1. Comparison of recipient survival time of rats in each group after liver transplantation. $* \mathrm{P}<0.01$ as compared with group $\mathrm{C}$. 


\section{Pathology and rejection grading of transplanted livers}

In group $\mathrm{C}$, transplantation rejection escalation peaked at the 14 th day, and the rejection grading period was significantly higher than that of groups $\mathrm{A}$ or $\mathrm{B}(\mathrm{P}<0.05$ and $\mathrm{P}<0.01$, respectively). The exclusion grading trend of group $\mathrm{B}$ was similar to that of group $\mathrm{C}$, although its exclusion intensity was significantly lower than that of group $\mathrm{C}$, but higher than that of group $\mathrm{A}(\mathrm{P}<0.05$ and $\mathrm{P}<0.01$, respectively; Figure $2 \mathrm{~A})$.
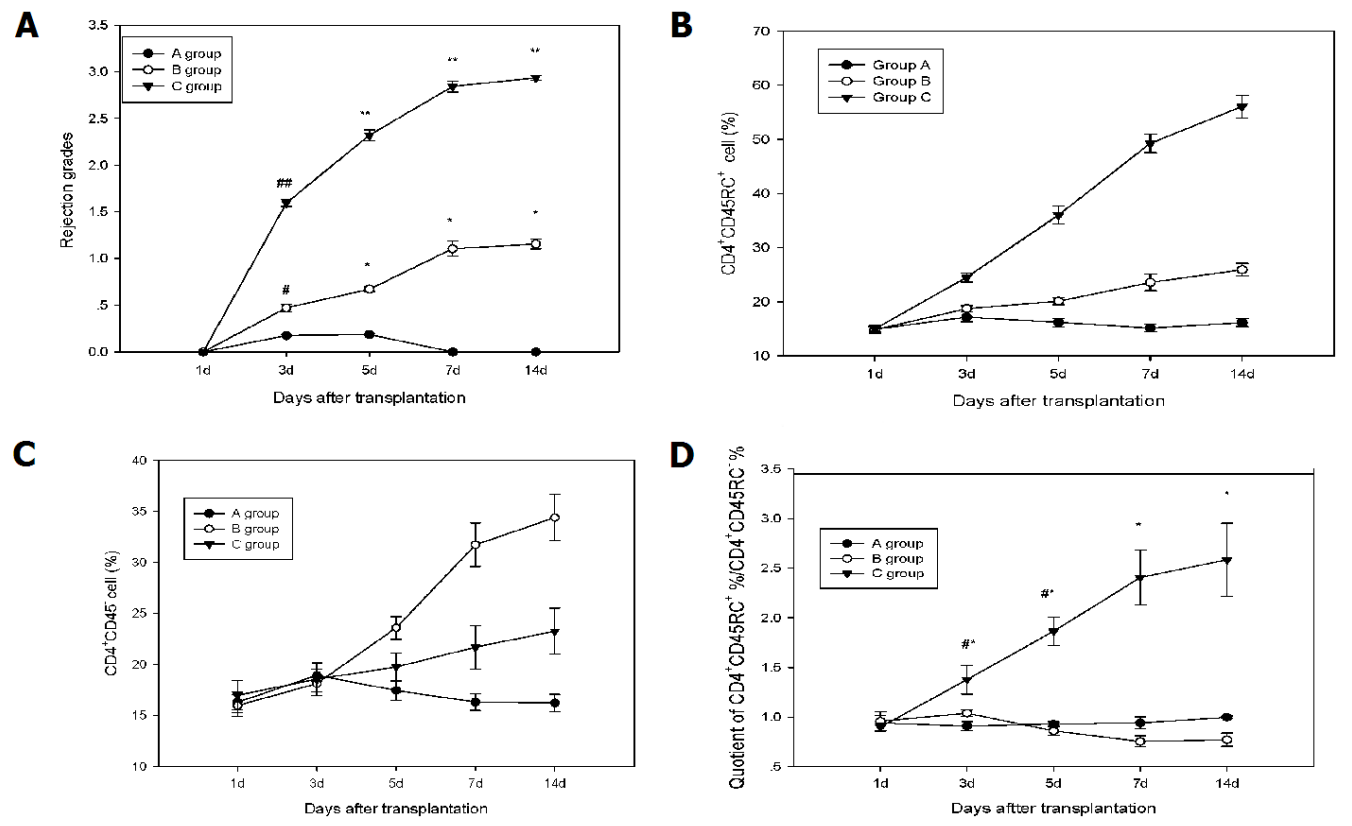

Figure 2. A. Transplantation rejection grading dynamic changes: ${ }^{\#} \mathrm{P}<0.05$ as compared with group $B$ and group $\mathrm{A}$; \#as compared with group $\mathrm{A} ;{ }^{* *} \mathrm{P}<0.01$ as compared with group $\mathrm{B}$ and group $\mathrm{A}$; *as compared with group A. B. Changes of $\mathrm{CD} 4{ }^{+} \mathrm{CD} 45 \mathrm{RC}^{+}$cell percentage in PBMC in different groups. C. Changes of $\mathrm{CD} 4{ }^{+} \mathrm{CD} 45 \mathrm{RC}^{-}$ cell percentage in PBMC in different groups. D. $\mathrm{CD} 4{ }^{+} \mathrm{CD} 45 \mathrm{RC}^{+} \% / \mathrm{CD}^{+} \mathrm{CD} 45 \mathrm{RC}^{-} \%$ ratio change; ${ }^{*} \mathrm{P}<0.01$ as compared with A group, $* \mathrm{P}<0.05$ as compared with $\mathrm{B}$ group.

\section{Flow cytometry receptor $\mathrm{CD}^{+}{ }^{+} \mathrm{CD} 45 \mathrm{RC}$ cells in peripheral blood}

As shown in Figure 2B, the percentage of $\mathrm{CD} 4{ }^{+} \mathrm{CD} 45 \mathrm{RC}^{+}$cells in the peripheral blood mononuclear cells increased in groups $\mathrm{C}$ and $\mathrm{B}$ after liver transplantation, and this increase was significantly higher in group C. As shown in Figure $2 \mathrm{C}$, the percentage of CD4 ${ }^{+} \mathrm{CD} 45 \mathrm{RC}^{-}$ cells in peripheral blood mononuclear cells also increased in groups $\mathrm{C}$ and $\mathrm{B}$ after liver transplantation, with a more significant increase observed in group B. As shown in Figure 2D, in group $\mathrm{C}$, the ratio of $\mathrm{CD} 4{ }^{+} \mathrm{CD} 45 \mathrm{RC}^{+}$to $\mathrm{CD} 4{ }^{+} \mathrm{CD} 45 \mathrm{RC}^{-}$in the recipients' peripheral blood increased by the $3 \mathrm{rd}$ day after transplantation, and peaked at the 14th day, whereas in group A, the increase and peak occurred at the 3rd and 5th days, respectively $(\mathrm{P}<0.01)$. After 3 days, 
compared with group B, the increase was also significantly higher in group A ( $\mathrm{P}<0.01$ or $<$ $0.05)$. An example of the flow cytometry results from group B at 5 days after transplantation is shown in Figure 3.
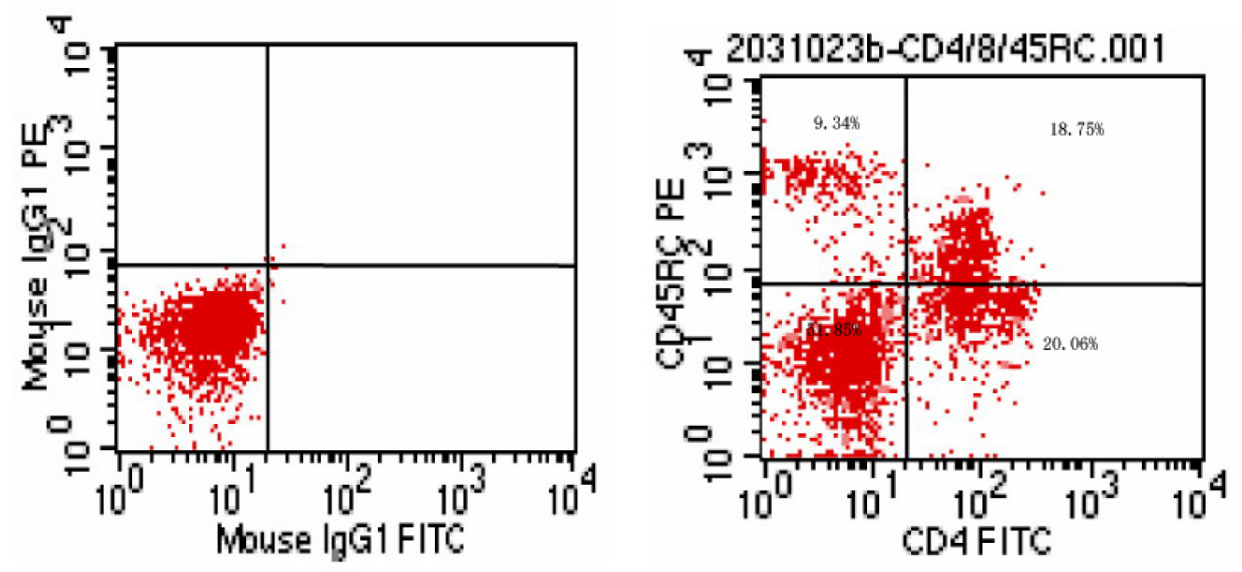

Figure 3. $\mathrm{CD}^{+} \mathrm{CD} 45 \mathrm{RC}^{+}$cell percentage changes in peripheral blood mononuclear cells.

\section{Correlation between the $\mathrm{CD}^{+} \mathrm{CD}^{-} 5 \mathrm{RC}^{+}$to $\mathrm{CD}^{+} \mathrm{CD} 45 \mathrm{RC}^{-}$ratio in peripheral blood of recipients with the donor liver pathology rejection grade}

The ratio of $\mathrm{CD} 4{ }^{+} \mathrm{CD} 45 \mathrm{RC}^{+}$to $\mathrm{CD} 4{ }^{+} \mathrm{CD} 45 \mathrm{RC}^{-}$in the peripheral blood of group B recipients was negatively correlated with the donor liver pathology rejection grade $(\mathrm{r}=-0.565, \mathrm{P}$ $<0.01)$. In contrast, this relationship was positive in group $\mathrm{C}(\mathrm{r}=0.745, \mathrm{P}<0.01)$.

\section{DISCUSSION}

Recent studies have confirmed that $\mathrm{CD} 4{ }^{+} \mathrm{CD} 45 \mathrm{RC}^{+}$and $\mathrm{CD} 4{ }^{+} \mathrm{CD} 45 \mathrm{RC}^{-} \mathrm{T}$ rat peripheral blood lymphocytes represent Th1 and Th2 cells, respectively (Hylkema et al., 2000; Chung et al., 2000), and the balance of the two subsets can be directly determined. In this study, we used flow cytometry to examine the expression of a series of peripheral blood lymphocyte surface antigens in an allogeneic liver transplantation rat model. $\mathrm{CD} 4^{+} \mathrm{T}$ lymphocytes can be divided into Th1 and Th2 as two functional subsets. Th1 cells correlate with cellular immunity, while Th2 cells are mainly related to auxiliary humoral immunity, and their balance directly affects immune function. When activated under certain conditions, neonatal CD4 $4^{+} \mathrm{Th}$ cells can be directed to differentiate into Th1 or Th2 cells, and conditions of the cytokine microenvironment play a major role in this process (Paul and Seder, 1994; Constant and Bottomly, 1997). Th1 and Th2 cell responses are also affected by the mutual adjustment of their respectively produced cytokines. For example, Th1 cells produce IFN- $\gamma$, which can inhibit Th2 cell development and humoral immunity, while Th2 cells produce IL-4 and IL-10, which can inhibit Th1 cell development, activation, and the activation and bactericidal capacity of МФ. Some studies have shown that Th1 is highly expressed during rejection, whereas Th2 is 
expressed mainly during tolerance or long-term acceptance of transplanted organs (Amlot et al., 1995; Quiroga et al., 2006).

As shown in Figure $2 \mathrm{~B}$ and $\mathrm{C}, \mathrm{CD} 4{ }^{+} \mathrm{CD} 45 \mathrm{RC}^{+}$and $\mathrm{CD} 4{ }^{+} \mathrm{CD} 45 \mathrm{RC}^{-}$were essentially expressed at baseline levels in the control, group $\mathrm{A}$, except for a mild elevation observed on the 3rd day after transplantation. The ratio of $\mathrm{CD}^{+} \mathrm{CD} 45 \mathrm{RC}^{+}$to $\mathrm{CD} 4{ }^{+} \mathrm{CD} 45 \mathrm{RC}^{-}$(Figure 2D) also remained relatively stable in the control group, in which the recipients' survival time exceeded 100 days after transplantation. The early rejection grades demonstrated no apparent rejection, indicating that the $\mathrm{CD} 4{ }^{+} \mathrm{CD} 45 \mathrm{RC}^{+}$to $\mathrm{CD}^{+} \mathrm{CD} 45 \mathrm{RC}^{-}$balance plays a critical role in maintaining transplant immunity. Figure $2 \mathrm{~B}$ and $\mathrm{C}$ show that in groups $\mathrm{B}$ and $\mathrm{C}, \mathrm{CD} 4{ }^{+} \mathrm{CD} 45 \mathrm{RC}^{+}$ and $\mathrm{CD} 4{ }^{+} \mathrm{CD} 45 \mathrm{RC}^{-}$have different degrees of expression, but the trend is not clear. In Figure $2 \mathrm{D}$, this trend is illustrated for group $\mathrm{B}$, in which the $\mathrm{CD} 4{ }^{+} \mathrm{CD} 45 \mathrm{RC}^{+}$to $\mathrm{CD} 4{ }^{+} \mathrm{CD} 45 \mathrm{RC}^{-}$ratio decreases below the level of the control group, and is negatively correlated with rejection grades. The average survival time of this group was also greater than 100 days, indicating the long-term survival and immune tolerance level for rat liver transplantations. This result suggests that immune tolerance is reached when Th1 cells offset to Th2 cells after rat liver transplantation, and confirms that $\mathrm{Th} 2$ is expressed under immune tolerance or long-term acceptance. In group $\mathrm{C}$, rejection grading was positively correlated with the $\mathrm{CD} 4{ }^{+} \mathrm{CD} 45 \mathrm{RC}^{+}$to $\mathrm{CD} 4{ }^{+} \mathrm{CD} 45 \mathrm{RC}^{-}$ratio, which increased with higher rejection grades mainly due to an increase in $\mathrm{CD}^{+} \mathrm{CD} 45 \mathrm{RC}^{+}$. The survival time of the group $\mathrm{C}$ recipients was very low, at $34.3 \pm 3.56$ days. $\mathrm{CD}^{+} \mathrm{CD} 45 \mathrm{RC}^{+}$was mainly expressed in the process of rejection, confirming the hypothesis that Th2 cells contribute to long-term acceptance. To avoid rejection in the rat liver transplantation models in group B, CsA was applied, which may be involved in many immune reactions (Queen et al., 1989; Vincenti et al., 1997; Williams et al., 1999). CsA inhibition is generated by cytotoxic T-lymphocytes, and its antigen receptor is the cyclosporin binding protein, cyclophilin. At the gene level, CsA inhibits the production and release of IL-2 and IFN- $\gamma$ (Grinyo et al., 2004; Zhang et al., 2007). IL-2 is a growth factor that is correlated with $\mathrm{T}$ cell survival, differentiation, and proliferation (Amlot et al., 1995), and IFN- $\gamma$ is a critical factor (Quiroga et al., 2000) promoting Th1 cell differentiation. Kovarik et al. (1996) showed that CsA could stimulate promoter activity of the transforming growth factor- $\beta$ (TGF- $\beta$ ) gene, thereby increasing TGF- $\gamma$ expression. Furthermore, Cho et al. (2007) showed that in vivo or in vitro administration of CsA inhibited the nuclear translocation of $\mathrm{NF}-\mathrm{\kappa B}$, thereby inhibiting dendritic cell (DC) maturation. Mature DCs play a key role in allograft rejection, in which immature DCs can prolong the survival of transplanted organs. Therefore, our future research aims to further explore and clarify the role of CsA in organ transplantation success.

\section{ACKNOWLEDGMENTS}

Research supported by grants from the Natural Science Foundation of Shandong (\#Y2007C165).

\section{REFERENCES}

Amlot PL, Rawlings E, Fernando ON, Griffin PJ, et al. (1995). Prolonged action of a chimeric interleukin-2 receptor (CD25) monoclonal antibody used in cadaveric renal transplantation. Transplantation 60: 748-756.

Cho ML, Ju JH, Kim KW, Moon YM, et al. (2007). Cyclosporine A inhibits IL-15-induced IL-17 production in CD4+ T cells via down-regulation of PI3K/Akt and NF-kappaB. Immunol. Lett. 108: 88-96. 
Chung YH, Jun HS, Son M, Bao M, et al. (2000). Cellular and molecular mechanism for Kilham rat virus-induced autoimmune diabetes in DR-BB rats. J. Immunol. 165: 2866-2876.

Constant SL and Bottomly K (1997). Induction of Th1 and Th2 CD4+ T cell responses: the alternative approaches. Annu. Rev. Immunol. 15: 297-322.

Garvy BA, King LE, Telford WG, Morford LA, et al. (1993). Chronic elevation of plasma corticosterone causes reductions in the number of cycling cells of the B lineage in murine bone marrow and induces apoptosis. Immunology 80: 587-592.

Grinyo JM, Cruzado JM, Millan O, Caldes A, et al. (2004). Low-dose cyclosporine with mycophenolate mofetil induces similar calcineurin activity and cytokine inhibition as does standard-dose cyclosporine in stable renal allografts. Transplantation 78: 1400-1403.

Hylkema MN, van der Deen M, Pater JM, Kampinga J, et al. (2000). Single expression of CD45RC and RT6 in correlation with T-helper 1 and T-helper 2 cytokine patterns in the rat. Cell. Immunol. 199: 89-96.

Kamada N and Calne RY (1983). A surgical experience with five hundred thirty liver transplants in the rat. Surgery 93: 64-69.

Kemnitz J, Ringe B, Cohnert TR, Gubernatis G, et al. (1989). Bile duct injury as a part of diagnostic criteria for liver allograft rejection. Hum. Pathol. 20: 132-143.

Kovarik JM, Rawlings E, Sweny P, Fernando O, et al. (1996). Prolonged immunosuppressive effect and minimal immunogenicity from chimeric (CD25) monoclonal antibody SDZ CHI 621 in renal transplantation. Transplant. Proc. 28: 913-914.

Martín J, de Sequera P, Quiroga JA, Rico M, et al. (2000). Role of haemodialysis and hepatitis c virus infection in spontaneous and induced cytokine production of patients with chronic renal disease. Cytokine 12: 1248-1252.

Mowat AP (1987). Liver disorders in children: the indications for liver replacement in parenchymal and metabolic diseases. Transplant. Proc. 19: 3236-3241.

Paul WE and Seder RA (1994). Lymphocyte responses and cytokines. Cell 76: 241-251.

Queen C, Schneider WP, Selick HE, Payne PW, et al. (1989). A humanized antibody that binds to the interleukin 2 receptor. Proc. Natl. Acad. Sci. U. S. A. 86: 10029-10033.

Quiroga MF, Pasquinelli V, Martinez GJ, Jurado JO, et al. (2006). Inducible costimulator: a modulator of IFN-gamma production in human tuberculosis. J. Immunol. 176: 5965-5974.

Starzl TE, Esquivel C, Gordon R and Todo S (1987). Pediatric liver transplantation. Transplant. Proc. 19: 3230-3235.

Vincenti F, Lantz M, Birnbaum J, Garovoy M, et al. (1997). A phase I trial of humanized anti-interleukin 2 receptor antibody in renal transplantation. Transplantation 63: 33-38.

Williams KA, Thiel MA and Zola H (1999). The new-generation therapeutic anti-CD25 monoclonal antibodies. Transplantation 68: 1228-1229.

Yang ZL, Zheng SS and Shen KZ (2006). Cause analysis and preventive measures of donor liver reperfusion in rat liver transplantation. Yi Xue Yan Jiu Sheng Xue Bao 19: 221-224.

Zhang XG, Lu Y, Wang B, Li H, et al. (2007). Cytokine production during the inhibition of acute vascular rejection in a concordant hamster-to-rat cardiac xenotransplantation model. Chin. Med. J. 120: 145-149. 